\title{
General Psychiatry Atropine eye-drop-induced acute delirium: a case report
}

\author{
Prashant Maravi, ${ }^{1}$ Dheerendra Kumar Mishra (D) , ${ }^{1}$ Amrendra Singh, ${ }^{1}$ Vijay Niranjan ${ }^{2}$
}

To cite: Maravi P, Mishra DK, Singh A, et al. Atropine eyedrop-induced acute delirium: a case report. General Psychiatry 2020;33:e100125. doi:10.1136/ gpsych-2019-100125

Received 07 August 2019 Revised 14 February 2020 Accepted 17 February 2020
Check for updates

(c) Author(s) (or their employer(s)) 2020. Re-use permitted under CC BY-NC. No commercial re-use. See rights and permissions. Published by BMJ.

${ }^{1}$ Department of Psychiatry, Shyam Shah Medical College, Rewa, India

${ }^{2}$ Department of Psychiatry, M.G.M. Medical College, Indore, India

Correspondence to Dr Dheerendra Kumar Mishra; mdheerendra.ssmc@gmail.com

\section{ABSTRACT}

Atropine is an anticholinergic drug which is used in both parental and topical routes. Topical eye-drops of atropine sulfate are used as mydriatic and cycloplegics. Parental atropine-induced delirium is well known but topical atropine eye-drop-induced delirium cases are very limited in literature. In this case report, an elderly man underwent cataract surgery and developed delirium after the use of $1 \%$ atropine sulfate eye-drops as prescribed. This case supports the notion that even atropine eye-drops can cause delirium in patients at therapeutic doses in elderly.

\section{INTRODUCTION}

Atropine is an anticholinergic natural alkaloid derived from Atropa belladonna and Datura stramonium. ${ }^{1}$ Atropine is a competitive antagonist of the muscarinic acetylcholine receptor types M1, M2, M3, M4 and $\mathrm{M} 5 .^{2}$ It is given by both parenteral and topical routes. Parenteral atropine is used in preanaesthetic medications, organophosphate poisoning, vagolytic agents and so on. ${ }^{3}$ Topical atropine eye-drops are used to treat uveitis, early amblyopia, iridocyclitis and ciliary block (malignant) glaucoma; postcataract surgery is recommended in order to prevent uveitis, which is one of the postoperative complications. ${ }^{4}$

Anticholinergic medications (eg: atropine) are known to produce delirium. M1 receptors are located primarily in the central nervous system and are involved in perception; attention and cognitive functioning and delirium are associated with the antagonism of postsynaptic M1 receptors. ${ }^{5}$ These medications are used widely in clinical settings and, generally, clinicians expect the possibility of the central anticholinergic syndrome (CAS) with parenteral route mainly. However, there are few case reports that describe this CAS and delirium with topical preparation of anticholinergics. We also report the case of an elderly man who developed delirium with the use of topical atropine preparation.

\section{CASE HISTORY}

A 65-year-old married man with no significant history/family history of psychiatric illness was brought to psychiatry emergency a day after his cataract surgery with acute-onset abnormal behaviour characterised by picking up at imaginary objects, trying to remove eye bandages, irrelevant talk, confused and trying to run away since 2 hours. As per protocol followed in the ophthalmology department, the patient was discharged the next day following surgery as he was postoperatively alright. After the application of atropine sulfate $1 \%$ eye-drops thrice a day as per prescription, he developed abnormal behaviour. There was no history of any associated medical illness. His preoperative workup showed no clinical and laboratory parameter abnormality and thus was marked as fit for the surgery. After admission in the psychiatry ward, the patient was evaluated clinically and he was disoriented to time and place with impaired attention, concentration and increased psychomotor activity. Formal mental status examination was not possible at that time. Necessary routine investigations including complete blood count, liver function test, renal function test, serum electrolyte, blood sugar, thyroid profile, urine examination, ECG, CT scan of brain, ultrasonography of abdomen and chest X-ray were done to find the cause of delirium but all the parameters were found to be within normal limits. There was no history of any substance abuse as well. Worsening of clinical symptoms in the evening was observed in the ward. We used intramuscular haloperidol injection $5 \mathrm{mg}$ in two divided dosages. It resulted in reduction of psychomotor activities but the patient continued to be delirious. After a brief literature review, a possibility of topical atropine-induced delirium was considered and it was stopped. After stopping the atropine eye-drops, the symptoms improved over the next $8-10$ hours. A rechallenge was also attempted to confirm and it was observed that the patient's symptoms again worsened in a day, thus it was stopped and the patient again improved over the next day. ${ }^{6}$ Adverse drug reaction probability scale score was 8 in 
index case which corresponds to probable adverse reaction (delirium) due to atropine sulfate $1 \%$ eye-drops.

\section{DISCUSSION}

The patient discussed in our case experienced a delirious state thought to be associated with topical atropine $1 \%$ eye-drops. CAS was initially described by Longo in 1966. Acetylcholine is important in regulating many functions, including the sleep-wake cycle, memory, alertness, orientation, and so on. CAS results due to antagonism of cholinergic neurotransmission at muscarinic receptors. Clinical features of this syndrome include delirium, hallucinations, agitation, convulsions and hyperactive state. CAS is rare but may occur at the therapeutic doses due to idiosyncrasy. Advanced age is also a risk factor described in the literature. ${ }^{7}$

Systemic absorption of the drug can occur transconjunctively or through nasolacrimal duct through highly vascular nasal mucosa. Previous literature on the systemic absorption of drugs indicates that $30 \%-80 \%$ dose may enter the general circulation after conjunctival instillation. Eye-drops can be absorbed by capillaries and reach the brain through angulus venosus of deep cerebral veins and cavernous sinuses. Atropine is a lower molecular weight molecule and can cross blood-brain barrier easily. ${ }^{8}$

Diagnosis of this state is difficult and needs exclusion of other possibilities, for example, substance abuse, acute psychosis, epilepsy, metabolic delirium, intracranial masses or oedemas and so on. ${ }^{9}$ In our case, there was no such abnormality found in history, clinical examination, lab investigations and neuroimaging. There was temporal relationship between topical atropine eye-drops use and development of delirium which was again confirmed with rechallenge. The symptoms improved after cessation of the administration of eye-drops. All these factors suggested the association of delirium with topical atropine eye-drops usage in our case.

Thus clinicians should remain aware about the possibility of this rare yet serious adverse drug reaction so that it can be identified and managed promptly. Also, there should be judicious use of atropine topical eye-drops in vulnerable elderly population.

Acknowledgements The authors thank the residents of the Department of Psychiatry of Shyam Shah Medical College Rewa for technical support.

Contributors PM, DKM: observations; conceptualise the case. PM, AS: detailed assessment, evaluation; conclude the case. DKM, VN: manuscript writing, proofreading and literature review.

Funding The authors have not declared a specific grant for this research from any funding agency in the public, commercial or not-for-profit sectors.

Competing interests None declared.

Patient consent for publication Not required.

Provenance and peer review Not commissioned; externally peer reviewed.

Open access This is an open access article distributed in accordance with the Creative Commons Attribution Non Commercial (CC BY-NC 4.0) license, which permits others to distribute, remix, adapt, build upon this work non-commercially, and license their derivative works on different terms, provided the original work is properly cited, appropriate credit is given, any changes made indicated, and the use is non-commercial. See: http://creativecommons.org/licenses/by-nc/4.0/.

ORCID iD

Dheerendra Kumar Mishra http://orcid.org/0000-0002-5068-2922

\section{REFERENCES}

1 Caksen H, Odabaș D, Akbayram S, et al. Deadly nightshade (Atropa belladonna) intoxication: an analysis of 49 children. Hum Exp Toxicol 2003;22:665-8.

2 Rang D. Ritter and more: pharmacology. Elsevier, 2003: 139.

3 Smulyan $\mathrm{H}$. The beat goes on: the story of five ageless cardiac drugs. Am J Med Sci 2018;356:441-50.

4 Hamilton RJ, Duffy NA. Tarascon Pharmacopoeia. 15th edn. Anne Spencer, 2014: 386.

5 Praticò C, Quattrone D, Lucanto T, et al. Drugs of anesthesia acting on central cholinergic system may cause post-operative cognitive dysfunction and delirium. Med Hypotheses 2005;65:972-82.

6 Naranjo CA, Busto U, Sellers EM, et al. A method for estimating the probability of adverse drug reactions. Clin Pharmacol Ther 1981;30:239-45.

7 Sharma K, Sood T, Tomar M, et al. Case series of Cyclogyl-induced delirium in elderly. Sudanese J Ophthalmol 2016;8:39-41.

8 Tune LE, Bylsma FW, Hilt DC. Anticholinergic delirium caused by topical homatropine ophthalmologic solution: confirmation by anticholinergic radioreceptor assay in two cases. J Neuropsychiatry Clin Neurosci 1992;4:195-7.

9 Panchasara A, Mandavia D, Anovadiya AP, et al. Central anticholinergic syndrome induced by single therapeutic dose of atropine. Curr Drug Saf 2012;7:35-6.

Dr. Dheerendra Kumar Mishra graduated (M.B.B.S.) from Shyam Shaha Medical College Rewa (M.P.) India, He did his post graduation (M.D. Psychiatry) in June 2017, and also received the Diplomat of National Board (Psychiatry) from the National Board of Examination. He is currently working as an assistant professor in the Department of Psychiatry. His research interests include advances in psychiatric treatment, mood disorders, psychopharmacology and geriatric psychiatry. 